as well as by poaching for the fur trade. Four years ago, the Fauna Preservation Society of London estimated that 50,000 leopards were killed annually in East Africa. Speaking of leopards, the museum received a curious letter from a woman whose husband had shot six leopards. She had the skins made into a coat, but she prudently kept all the scraps. Now she was tired of the coat and wanted to know if we could transform it back into a leopard again. Stuffed, I presume. It was hard to be polite as I wrote back that the answer was "No!" Needless to say, her question haunts me. Someday we may want to transform the last zoo leopard back into a wild leopard and find we can't."

\title{
WHERE ARE THEY NOW?
}

This extract from Wilfrid Blunt's poem "Satan Absolved", from the speech of the Angel of Pity, is reprinted by kind permission of the Syndics of the Fitzwilliam Museum, Cambridge. Wilfrid Scawen Blunt died in 1922.

From the deep Central Seas

To the white Poles, Man ruleth pitiless Lord of these, And daily he destroyeth. The great whales he driveth Beneath the northern ice, and quarter none he giveth, Who perish there of wounds in their huge agony.

He presseth the white bear on the white frozen sea And slaughtereth for his pastime. The wise amorous seal

He flayeth big with young; the walrus cubs that kneel But cannot turn his rage, alive he mangleth them, Leaveth in breathing heaps, outrooted branch and stem. In every land he slayeth. He hath new engines made Which no life may withstand, nor in the forest shade Nor in the sunlit plain, which wound all from afar, The timorous with the valiant, waging false war, Coward, himself unseen. In pity, Lord, look down On the blank widowed plains which he hath made his own By right of solitude. Where, Lord God, are they now, Thy glorious bison herds, Thy ariels white as snow, Thy antelopes in troops, the zebras of Thy plain? Behold their whitened bones on the dull track of men. Thy elephants, Lord, where? For ages Thou didst build Their frames' capacity, the hide which was their shield No thorn might pierce, no sting, no violent tooth assail, The tusks which were their levers, the lithe trunk their flail.

Thou strengthenedst their deep brain. Thou madest them wise to know And wiser to ignore, advised, deliberate, slow, Conscious of power supreme in right. The manifest token Of Thy high will on earth, Thy natural peace unbroken, Unbreakable by fear. For ages did they move Thus, kings of Thy deep forest swayed by only love. Where are they now, Lord God? 




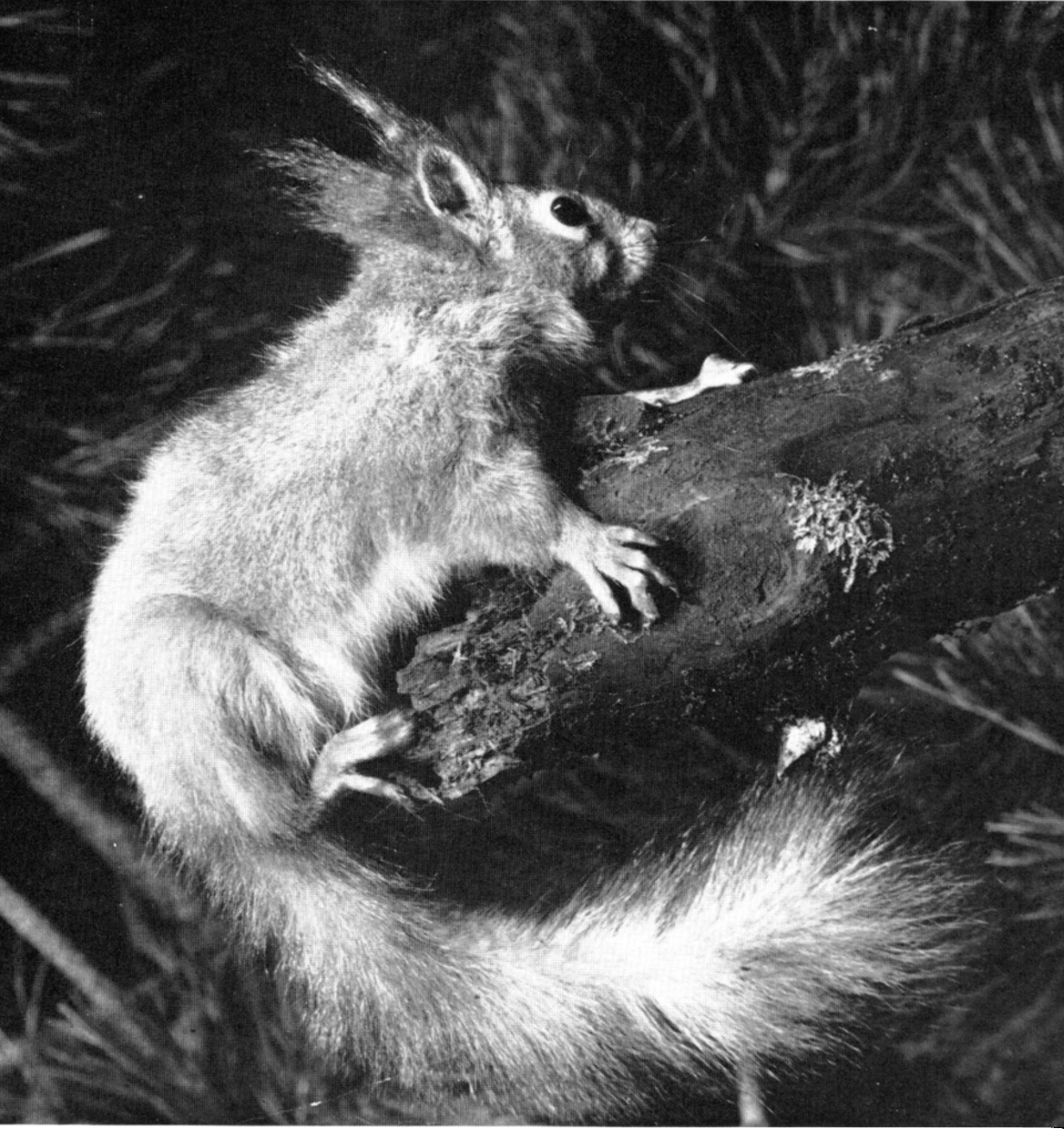

Plate 10: RED SQUIRREL, whose numbers have increased greatly in the Commission's forests in East Anglia.

Photograph by John Markham 